\title{
Zgodnje obdobje slovenske ekspresionistične kratke proze in njene slogovne prvine
}

\author{
JoŽICA ČEh STEger \\ Univerza v Mariboru, Filozofska fakulteta, Koroška cesta 160, \\ SI-2000 Maribor, jozica.ceh@uni-mb.si
}

\begin{abstract}
Novejše raziskave potrjujejo, da je začetek slovenske ekspresionistične kratke proze sovpadel z začetkom prve svetovne vojne, ko je $\mathrm{v}$ reviji Dom in svet ob Cankarjevih "podobah iz sanj« začel objavljati distorzične psihološke črtice $\mathrm{z}$ etično obsodbo vojne tudi mladi rod pisateljev (France Bevk, Stanko Majcen, Ivan Dornik, Narte Velikonja idr.). Ob raznovrstnosti stilnih postopkov se razprava osredinja na model temnih sanj v Cankarjevih simbolno-alegoričnih in metaforičnih »podobah« ter na Bevkovo vojno črtico, za katero so značilni parabolični postopki, pisateljev vstop v ekspresionistično stilno paradigmo pa je potekel ob disharmoniji zvoka, grotesknih podobah, barvni abstrakciji in retoričnem govoru.
\end{abstract}

Recent studies have shown that the beginnings of Slovene expressionist short prose overlap with the beginning of the First World War, when alongside Cankar's "podobe iz sanj (images from dreams)", a younger generation of writers (France Bevk, Stanko Majcen, Ivan Dornik, Narte Velikonja, etc.) began publishing distorted psychological short stories in the Journal Dom in svet (Home and World) containing ethical judgments of war. The present contribution focuses on various stylistic procedures and especially on the model of ominous dreams associated with Cankar's symbolic-allegorical and metaphoric "images", and on Bevk's war short story involving characteristic parabolic procedures, while its entry into the expressionist stylistic paradigm is evident in dissonance, grotesque images, abstract use of colours, and rhetorical speech.

Ključne besede: ekspresionizem, kratka proza, stil, Ivan Cankar, France Bevk

Key words: expressionism, short prose, style, Ivan Cankar, France Bevk 


\section{Stanje raziskav}

Od osemdesetih let prejšnjega stoletja je v evropskem kulturnem prostoru (Scheffer, 1982, Krull, 1984, Jens, 1997, Fähnders, 2001, Nemec, 2002) zaznati intenzivno raziskovanje ekspresionistične pripovedne proze. Pogosta teza, da se ekspresionistična stilna paradigma zaradi poudarjene nemimetičnosti ni mogla uveljaviti v pripovedni prozi, je lahko veljavna za roman, ne pa tudi za kratko prozo, saj je bila ta že od konca 19. stoletja, v ekspresionizmu pa še prav posebej, močno odprta za neepične stile in disparatne modele.

Walter Fähnders (2001) ugotavlja, da sta se v nemški književnosti ekspresionistična poezija in kratka proza razvijali vzporedno. Na pomembnost in dobre primere slednje je v uvodu k zbirki Glosse, Aphorismus, Anekdote (1913) opozoril že Kurt Pinthus, sicer bolj poznan kot urednik antologije nemške ekspresionistične poezije (Menscheitsdämmerung, 1920). Leta 1914 je med drugim izdal knjigo filmskih sinopsisov (Kinobuch, 1914) in opozoril na simultani stil in vrsto hibridnih zvrsti in žanrov, kot so manifesti, potopisi, filmski sinopsisi, eseji, aforizmi, ki jih je zaradi narativnih vložkov mogoče uvrstiti na obrobje fikcijske kratke proze. Ob upoštevanju žanrskih hibridov postane slika ekspresionistične kratke proze še zapletenejša, obenem so posamezne prvine, kot so redukcija epskih prvin, preseganje žanrskih mej, refleksivnost in metabesedilnost, kar v največji meri zaznamovale tudi povsem fikcijsko ekspresionistično kratko prozo. Bernd Sheffer (cit. po Fähnders 2000: 13) je med drugim prepričan, da je pripovedna proza za ekspresionistično poetiko celo primernejša od poezije, saj je ta že po svojih formalnih določilnicah nujno bolj zaprta in manj variabilna. Krešimir Nemec (2002: 87) pa je ugotovil, da so se $\mathrm{v}$ hrvaški kratki prozi ekspresionistične značilnosti povečevale sorazmerno $\mathrm{s}$ kratkostjo in z neepičnostjo te pripovedne forme.

$\mathrm{V}$ zadnjih desetletjih se je raziskovalni interes za ekspresionistično prozo tako v nemškem (Fähnders 2001: 13) kot hrvaškem (Nemec 2002: 85) kulturnem prostoru sicer povečal, vendar ostaja ta kljub obsežni tekstualni bazi še zmeraj premalo raziskana. Podobno lahko zapišemo tudi za raziskave slovenske ekspresionistične proze. Literarna zgodovina se je z njo najizraziteje ukvarjala $\mathrm{V}$ osemdesetih in na začetku devetdesetih let prejšnjega stoletja, pri čemer mislimo na raziskave Franca Zadravca, Helge Glušič, Lada Kralja, na zbornik Obdobje ekspresionizma v slovenskem jeziku, književnosti in kulturi (1984) in monografske razprave o posameznih avtorjih (o Kosovelu, Preglju, Jarcu idr.). V zborniku Slovenska kratka pripovedna proza (2006) so kratki prozi omenjene smeri posvečene le štiri razprave, nekoliko več pozornosti pa je v zadnjih letih tej tematiki namenila Slavistična revija. ${ }^{1}$

${ }^{1} \mathrm{~V}$ omenjenem zborniku mislimo na razprave Katje Mihurko Poniž (2006: 73-86), Alenke Jensterle Doležal (2006: 97-110), Lada Kralja (2006: 319-338) in Jožice Čeh (2006: 569-580), v Slavistični reviji pa predvsem na razprave Bojane Stojanović Pantović (2006: 33-40), Lada Kralja (2006: 205-220) in Gregorja Kocijana (2006: 329-348). 
Doslej edino monografijo o slovenski ekspresionistični prozi (Morfologija ekspresionističke proze, 2003), ki pomembno vključuje tudi kratko prozo, je napisala Bojana Stojanović Pantović. Upoštevajoč samostojne zbirke in periodični tisk je v primerjavi s Kraljem (1986) ugotovila obsežen in raznovrsten korpus slovenske ekspresionistične kratke proze ter se na podlagi zvrstnih in motivno-tematskih kriterijev osredinila na reprezentativna besedila posameznih avtorjev. Med drugim je opozarjala na rabo telegrafskega in simbolično-alegoričnega postopka, drugim stilnim vprašanjem pa se ni podrobneje posvečala.

\section{Struktura sanj kot model ekspresionistične podobe}

Ekspresionistična proza je nastajala po različnih avtorskih poetikah. Kot razpoznavne značilnosti te literature se pogosto navajajo kar značilni tematski sklopi oziroma toposi, poudarjena nemimetičnost in težnja po abstraktnosti, intenziteta subjekta, aktiviteta misli in čustev, izenačevanje estetike lepega in grdega, vizije, izrazito vizualne, hiperbolične in groteskne podobe, patetičnost, retoričnost, abstraktna barvna metaforika, kinematografski in simbolnoalegorični postopki, žanrska hibridnost, metabesedilnost itd. Zaradi precej ohlapnih določitev si teoretiki pogosto zastavljajo vprašanje o njeni poglavitni značilnosti. ${ }^{2}$ Lado Kralj je sicer leta 1986 menil, da je zgodovinska distanca za raziskovanje slovenske ekspresionistične proze še premajhna, vendar je obenem predlagal, da bi jo bilo mogoče zasilno fiksirati s Soklovim pojmovanjem kinematografskega in simbolično-paraboličnega stila, v nadaljevanju pa razglasil notranji monolog za temeljno značilnost ekspresionistične proze, čeprav je obenem priznal, da se s tem približuje modernemu romanu, romanu toka zavesti ali celo »novemu romanu« (1986: 168).

V sedemdesetih letih prejšnjega stoletja je Walter Sokel v svoji monografiji Literarischer Expressionismus (1970) za temeljno določilnico ekspresionističnega jezika razglasil model sanj, kakor ga je že leta 1901 razložil August Strindberg. V uvodu svoje Sanjske igre (Ein Traumspiel, 1901) je zapisal, da je poskušal posnemati nepovezano, vendar na videz logično obliko sanj, kakor jih reflektira sanjska zavest zunaj realnega časa in prostora. Sanje so po Strindbergu nekakšna kristalizacija duha oziroma sanjske zavesti. Iz rahle izhodiščne pripetosti na drobce iz resničnosti se v njih nato razmahne domišljija in plete nove modele, sestavljene iz spominov, dogodkov, svobodnih domislic, nepovezanosti in improvizacij. Vrnitev v resničnost se zgodi največkrat v trenutku najhujše more, zato je za sanjajočega to v nekem smislu tudi odrešitev (Strindberg 1917: 9). Tak model temnih sanj, je prepričan Sokel (1970), uporablja ekspresionistični jezik za slikovito izražanje nezavednih plasti duše. $\mathrm{Ob}$ zabrisani meji med subjektovo notranjostjo in zunanjim svetom se temna

${ }^{2}$ Silvio Vietta (1990: 19) je za temeljno določilnico ekspresionizma razglasil radikalno disociacijo subjekta, na podlagi katere se je lahko po njegovem mnenju razmahnila tudi ekspresionistična tema novega človeka, značilna zlasti za mesijanski tip ekspresionizma. 
podzavest, veliki strahovi in grozljive slutnje zvrstijo kot $\mathrm{v}$ sanjah ter oblikujejo v izrazito vizualne podobe. Težnja po abstraktnosti, duhovnosti in fantastiki ekspresionističnega jezika je poudarjena tudi s simboliko čistih barv.

\section{Začetki slovenske ekspresionistične kratke proze}

Zgodnje obdobje slovenske ekspresionistične kratke proze je Bojana Stojanović Pantović (2003) zamejila z letnicama 1914 in 1919, in sicer na osnovi najopaznejše spremembe $v$ tematski paradigmi, to je ob toposu prve svetovne vojne, ki je narekovala tudi opazne stilne inovacije. Ta kratka proza se je oblikovala v krogu dominsvetovcev pod mentorstvom Izidorja Cankarja. Iz njegovih kritiških zapisov so se že v prvem desetletju prejšnjega stoletja oglašale težnje po novem razmerju do sveta in umetnosti. Leta 1908 je bil ob oceni 19. zvezka Zabavne knjižnice kritičen do Cankarjevih novelističnih posnemovalcev, ki da nevede hodijo za žalostnim pogrebom njegovega Jakoba Nesreče, in obenem prepričan, da se »doba potepuške romantike in samovoljne lirike v prozi« (Iz. Cankar 1968: 274) že izteka. V isti kritiki je zaznal prehodno stanje med iztekajočo se subjektivistično prozo in napovedujočim se tokom realistične umetnosti. ${ }^{3}$ Ko je leta 1914 postal urednik Doma in sveta, je k sodelovanju ponovno pritegnil Ivana Cankarja ter vzgojil mladi rod poimpresionističnih pesnikov in pisateljev, med katerimi so France Bevk, Ivan Dornik, Stanko Majcen in Narte Velikonja ustvarili zametke slovenske ekspresionistične kratke proze. ${ }^{4}$ Ta je nastajala deloma še pod vplivom Cankarjeve lirsko razpoloženjske črtice, obenem se je iz nje tudi krčevito izvijala ter ustvarila novemu času in razmeram primernejši distorzični slogovni izraz, še zlasti ob tematizaciji prve svetovne vojne, njene etične obsodbe, razčlovečenja, groze in smrti.

\subsection{Cankarjeve Podobe iz sanj}

Cankarjeve protivojne črtice, objavljene v letih med 1914 in 1917 v Domu in sve$t u$ in nato izdane v zbirki Podobe iz sanj (1917), predstavljajo začetek slovenske ekspresionistične kratke proze tako po tematizaciji vojne in njene groze kakor tudi po nekaterih stilnih postopkih. Že naslovna kazalka zbirke opozarja na

\footnotetext{
${ }^{3}$ V omenjeni kritiki je Izidor Cankar pohvalil Finžgarjev smisel za realizem v upanju, da mu bo sledila tudi mlada generacija ter tako prebrodila obstoječo krizo romana (1968: 276).

${ }^{4}$ Izidor Cankar nad kratko prozo teh avtorjev ni bil posebej navdušen. Stanku Majcnu je celo potožil, da kot urednik dobiva sam drobiž, vendar Majcen s Cankarjem ni soglašal, saj je moč mladega rodu videl prav v drobižu in se je sredi leta 1914 razglasil za povestičarja: »Povestičar sem, po božji milosti najtanjem, najrevnejšem žarku, in to kljub vsem tistim, ki jim mojih malih, formalno še dokaj strogih in nič, pa nič črevastih povestic konca ni!« (Majcen 2000: 24).
} 
sanje, temu sledi pisateljevo pojasnilo o nastanku in strukturi črtic, iz katerega razberemo, da te podobe v marsičem ustrezajo opisanemu Strindbergovemu modelu sanj, njihova poetika pa se dovolj opazno razbira tudi v metabesedilnih delih posameznih črtic, kot so Gospod stotnik, Iz dna, Tretja ura, Ogledalo idr. Prvoosebni pripovedovalec večkrat navaja, da se mu porajajo podobe, ko je utrujen, na meji med budnostjo in spanjem ali ob nagli prebuditvi iz sanj. V črtici Ranjenci celo nedvoumno pravi, da vidi kot v sanjah, čeprav ne sanja:

Ali ko sem se oziral, se je pripetilo mojim očem nekaj čudnega, kar se pripeti časih edinole $\mathrm{v}$ sanjah, sanjalo pa se mi ni, bdeč sem stal ob svetlem in jasnem večeru na pragu tega prostranega vrta in kar sem videl, je bilo tako resnično in telesno, da bi lahko s prstom otipal (Cankar 1975: 58).

Cankarjeve temne podobe in vizije so povečana in iz ravnovesja premaknjena slika vojnih grozot. V opisanih stanjih se pripovedovalcu prikazuje resničnost kot v konkavnem ogledalu, segajočem od neba do zemlje (Ogledalo), drugje gleda skozi umazano šipo (Gospod stotnik) ali temno zagrinjalo (Pobratimi). Včasih si celo zaželi, da bi ne videl ničesar več, a obenem ve, da nastajajo podobe iz ponotranjenega pogleda:

Tudi jaz sem si želel marsikatero uro, da bi zatisnil oči za dolgo spanje brez sanj; in iztaknil bi si jih brez strahu in bolečine, če bi zares ne videl ničesar več; ali vem, da bi že v tistem trenotku ugledal grozoto $\mathrm{s}$ tisočerimi očmi, potisočerjeno (Kadet Milavec, 105).

Ker so grozljive, povečane in pokvečene podobe izraz notranje resničnosti, pripovedovalec ne potrebuje zunanjega očesa in se mu celo odpoveduje. Večkrat navaja, da so njegove oči utrujene, razbolele, motne, okamnele od strahu in groze ali da $\mathrm{v}$ določenem trenutku sploh ničesar ne vidijo več. $\mathrm{V}$ črtici Pobratimi beremo:

Razbolele so moje oči, vsaka podoba se jim prikaže prevelika, prenasilna, morda celo popačena: ali če jih zatisnem, vidim toliko jasnejše, kar je: srce gleda z očmi, ki nikoli ne lažejo (Cankar 1975: 99).

Misel o sanjski strukturi Cankarjevih črtic, zapisani tudi v naslovu in uvodnem pojasnilu h knjigi, je najobširneje razložena v metabesedilnem delu črtice Gospod stotnik:

Dokaj časa je že, da so zadobile moje sanje in pač sanje vsakega človeka čisto novo, prav posebno lice. Nič več niso puste blodnje, bežne megle, ki se brez smisla in vzroka prelivajo druga v drugo ter se nazadnje razpuhte v nič. Niso več tiste sanje, ki jih človek zjutraj strmeč ugleda z zaspanimi očmi ter napol smehljaje, napol jezen zamahne z roko.

Sanje, ki jih sanjam zdaj jaz in ki jih sanjaš zdaj ti, so senca prave resnice; pač so oblike strahotno povečane, nadvse čudno pokvečene in skrivenčene, toda resnica le ostane, spoznaš jo koj in srce ti je žalostno (Cankar 1975: 18).

V Cankarjevih Podobah iz sanj prevladujejo simbolno-alegorični in metaforični stilni postopki. Ker smo o tem pisali že na več mestih (Čeh 2001: 205-250; 2006: 569-580), se bomo v nadaljevanju omejili predvsem na Bevkove vojne 
črtice, objavljene v Domu in svetu. Med prvo svetovno vojno je bil ob Cankarju prav France Bevk najizrazitejši avtor črtic z vojno tematiko, z manjšim delom tovrstnih besedil sta mu sledila tudi Ivan Dornik ${ }^{5}$ in Stanko Majcen. ${ }^{6}$

\subsection{Bevkove vojne črtice}

Pisateljska pot Franceta Bevka se je pričela v krogu mladega roda dominsvetovcev pod intenzivnim mentorstvom Izidorja Cankarja. ${ }^{7}$ Pesmi, ki jih je pisal še pod vplivom Župančiča in Gradnika, je objavljal v Domu in svetu že od leta 1911, na večer prve svetovne vojne pa je začel objavljati tudi kratko prozo in postal po Cankarju eden najbolj čustveno prizadetih izpovedovalcev vojnih grozot in posledic, ki jih je ta pustila $\mathrm{v}$ človekovi duševnosti. Pred bralcem se $\mathrm{v}$ Bevkovih črticah zvrstijo mračne podobe, umirajoči vojaki na fronti in $\mathrm{v}$ zaledju, vojni begunci, dezerterji, ranjenci, duševni bolniki, blazneži, osamljena dekleta in žene, razpadle družine in intimne vezi med možem in ženo, porušene in zapuščene domačije. Vojaki se spreminjajo v rablje, doživljajo izjemne čustvene stiske in izbruhe, nepremostljivo osamljenost, apokaliptična videnja. V grozljivem času razpadlih etičnih in duhovnih vrednot Bevk zakliče tudi po novem človeku in se tako umesti med ustvarjalce mesijanskega tipa ekspresionistične kratke proze.

Na začetku dvajsetih let prejšnjega stoletja je Bevk večino črtic in novel, nastalih v letih od 1914 do 1922, izdal v knjižnih zbirkah Faraon ${ }^{8}$ (1922) in

${ }^{5}$ Tudi v Dornikovih vojnih črticah (Brez oči (DS 1917), Obtožnica (DS 1917), Pogovor s psom (DS 1918)) je v ospredju etični protest zoper ponižanje človeka. Mlad človek v njegovih črticah obsoja vojno, je vojni invalid, umira v svetu razpadlih etičnih vrednot, doživlja popolno socialno izolacijo, kriči po novem človeku itd. Stilno različne črtice temeljijo na monologih in kratkih dialogih pa tudi na simbolnih, zlasti živalskih podobah, vizijah ter hiperboličnih in vizualno učinkovitih metaforah. V zbirki z naslovom Brez oči so Dornikove vojne črtice in novele izšle šele leta 1930.

${ }^{6}$ Osrednji del Majcnovih črtic oziroma "povestic« do leta 1923 je nastal iz duhovne in literarne atmosfere dunajske moderne s prepoznavnimi elementi secesije (Čeh 2006: 389). Tema prve svetovne vojne je v Majcnovih črticah manj izrazita, pojavlja se v črticah Dnevnik (1921), Kvartir št. 8 (1916), Hči (1915) in Nevernik (1915). Stilno so prepoznavne po grotesknih podobah, zgoščenih dialogih, monologu in notranjem monologu. Ekspresionistična stilna paradigma je pri Majcnu najbolj opazna ob temi človekove eksistencialne krize, ta je zajela tudi vojaka na fronti (Nevernik), ki pravi o sebi, da ne more živeti niti umreti za domovino, nato pa je najizraziteje ubesedena v notranjem monologu zasutega rudarja v črtici Trenutek življenja (1917).

${ }^{7}$ Izidor Cankar je imel v letih med 1911 in 1917 intenzivno korespondenco s Francetom Bevkom, ki priča, da je tedaj mladega pesnika in pisatelja zelo spodbujal. V zvezi s prozo mu je svetoval branje literature in znanosti, ob Čehovu in Dostojevskem poglabljanje v psihološko oblikovanje individualnih značajev ter jasnost in konkretnost v izražanju (Iz. Cankar 1969: 360).

${ }^{8}$ V zbirki Faraon je zbranih petnajst črtic. Tri (Otrok, Begunec, Avditor) so bile leta 1919 objavljene v Slovencu, preostalih dvanajst v Domu in svetu med letoma 1914 in 1917: 
Rablji ${ }^{9}$ (1923). Prva je izšla pri Novi založbi v Trstu z likovno opremo Toneta Kralja, druga, katere temna vsebina je dodatno poudarjena še z linorezi Lojzeta Špacapana, v Gorici. Ker zbirki ob izidu nista bili več povsem aktualni, jima je kritika pripisala le še dokumentarno vrednost (Koblar 1951: 430). Tematsko in stilno mračne črtice iz zbirke Rablji so narativno še manj razvite kot v prvi zbirki, zato so se Koblarju zdele še najbliže slikarskim ali kiparskim stvaritvam. Imenoval jih je knjiga »temne poezije « in »nekakšen zapisnik sodobnih grehov« (1924: 256). Kritika je opozarjala tudi na očitno zgledovanje pri Ivanu Cankarju. Miran Jarc je v zbirki Rablji zaznal tudi opazne ruske literarne predloge, med katerimi je posebej navedel roman Jarem vojne Leonida Andrejeva, v povezavi s Cankarjevimi Podobami iz sanj pa je opozoril tudi na pomembne idejne in slogovne razlike:

/.../ vendar je med »Podobami iz sanj« in med Bevkovim ogledalom velika razlika. Cankar je zrastel iz brezna $\mathrm{v}$ metaforičnost sanj in odtod $\mathrm{v}$ zarje, ki jih že obliva godba sfer in njegova beseda poje kot blagovest, kot tolažba na tretje kraljestvo, ki utegne vzkliti kot roža v breznu. Bevk se le redkokdaj sprosti v metaforičnost (Jarc 1924: 699).

Čeprav so Bevkove zgodnje črtice nastale iz različnih pobud evropske psihološke proze (Dostojevski, Čehov, Andrejev), je bil Cankarjev zgled zagotovo najmočnejši. V besedilnem svetu nekaterih Bevkovih črtic je sklic na Cankarjevo predlogo več kot očiten, naj gre za tematizacijo matere, umetnika, etične problematike, človekove odtujenosti in seveda vojne groze. V stilu je ta navezava najopaznejša ob rabi grotesknih podob in paraboličnih stilnih postopkov.

\subsubsection{Zvočna razglašenost}

Leta 1914 je Bevk v Domu in svetu objavil prve črtice (Grešnik, Most samomorilcev, Iz leta 1914). Še posebej zadnja kaže na pisateljev premik v ekspresionistično stilno paradigmo, ki se mu je torej zgodil, še preden so bile v omenjeni reviji objavljene Cankarjeve »podobe iz sanj«. V črtici Iz leta 1914, sestavljeni iz ponavljajočih se pripovednih scen, je z grotesknim likom in zvočno razglašenostjo ubesedena močna intenziteta kolektivne psihoze tik pred prvo svetovno vojno. V zgodnjem jutru lomasti po vasi neznan blaznež, trka na vrata hiš, kliče na vojsko in je nekakšna alegorija groze. Grozljivo učinkuje že s svojo

Faraon (1917), Klic žene (1915), Praznota (1916), Kako je bilo? (1915), Vrnitev (1918), Sovka (1915), Črni piščanec (1915), Anuška pred poroto (1915), Most samomorilcev (1915), Podobni obrazi (1915), Grešnik (1914), Na četrti galeriji (1917).

${ }^{9}$ Zbirka Rablji šteje 22 črtic. V Domu in svetu je bilo objavljenih štirinajst črtic (Rablji (1915), V kritju (1919), Kralj Asram (1919), Bajka (1919), Nasmeh (1916), Štirje vinarji (1915), Zmagovalec (1915), V parku (1915), Prepovedan vhod (1915), Gospod Golob (1922), Pismo (1919), Odprto okno (1915), Oporoka (1916), Zlo (1915)), v Mentorju sedem (Mrlič (1917/18), Besede (1918/19), Tri suhe hruške (1917/18), Tancaj, Marko (1917/18), Mati (1916/17), Črna vest (1916/17), Povodna roža (1916/17)) in v Edinosti ena (Nedolžnost (1921)). 
pojavnostjo, še bolj pa z razglašeno pesmijo sredi jutranje tišine (»Krepko grlo je pelo prečudno melodijo s prečudnimi besedami «). Njegova hreščeča pesem se v obliki vodilnega motiva stopnjuje v krik, celo v neartikulirane glasove ter preroško oznanjanje strašne obsodbe (»Hooo-hoooj! Vsi bomo poginili!«).

Napeto duševno stanje se od neznanca prenaša tudi na vaščane (ob njegovem kričanju planejo iz spanja, mrzlično trepetajo, jokajo, kolnejo, molijo, stiskajo pesti idr.) in v pokrajino, katere jutranjo tišino s stopnjevanim ponavljanjem razbijejo razglašeni in vizualizirani zvočni pojavi (pesem, klici, retorični vzkliki, neartikulirani glasovi). Epiteti (močan, hreščeč glas, prečudna melodija, glas, temen, votel) in primere poudarjajo intenziteto in razglašenost zvoka, s konkretizacijskimi in sinestezijskimi glagolskimi metaforami pa se zvok utelesi tudi v neznosno in grozljivo vidno-slušno moč (besede ali pesem žgejo, udarjajo, tolčejo) sredi narave, $v$ grozo samo:

Kakor da bi glas donel iz neznanske globine, tako temen, strašen je bil. V majhnih presledkih se je oglašal krik in odmeval od hiš kot mrtvaška pesem (Bevk 1951: 168);

Pri slednji hiši je udaril s pestjo na vrata in kričal z glasom, kakor da bi pel psalm. Preroške besede so žgale huje kot ogenj, udarjale huje kot volovska žila (Bevk 1951: 168);

Njegova pesem se je gubila iz vasi in se vračala, tolkla na vrata in žvenketala na šipah (Bevk 1951: 169).

Grozljiva vizualizacija zvočne moči v pokrajini (v črtici Iz leta 1914) kaže na Bevkov vstop v ekspresionizem, vendar je pisatelj ohranjal še impresionistično razpoloženjski opis pokrajine, kakor je razvidno iz uvodnega dela iste črtice:

Jutro je. Nebo je od vzhoda pobledelo, dobilo zlat sijaj, ki se je bolj in bolj prelival v srebrno bleščavo, in zadnja zvezda je hitela, da zatone. Griči so dvignili svoje prsi v bujni zrak, poln življenja, in globoko zasopli, zganile so se trave in drevesa (Bevk 1951: 167).

Pisateljeva odločitev za novo stilno paradigmo je bila postopna in je tematizirana tudi v avtopoetski črtici Odprto okno (DS 1915). ${ }^{10}$

\subsubsection{Razčlovečenje in animalizacijska metafora}

Bevkove vojne črtice so osredinjene na etično in psihološko obsodbo vojne, na kar je opozorila že sočasna kritika. Juš Kozak (1923: 387) je denimo ob črticah iz prve Bevkove zbirke zapisal, da so izraz lirične duše in na papir izlito resnično vojno gorje. Črtice (Iz leta 1914, Zlo, Tri suhe hruške, Begunec) razkrivajo duševno in etično izmaličeno podobo človeka kot najhujše zlo. Vojna

\footnotetext{
${ }^{10}$ Prvoosebni pripovedovalec oziroma salonski umetnik dvomi o izrazni moči besede, navdušuje se nad večno lepoto trenutka, ugledano v slikarjevi potezi, gibu plesalca ali akordu, toda obenem spozna, da v novih razmerah lepotni izraz ni več aktualen (»Gorje $m u, k d o r$ bi se objemal s tistimi, ki capljajo, se bratil z onimi, ki gredo, in ne dirjal poleg velikega, breztelesnega jezdeca, kateri ima sam nesmrtnost in življenje v očeh - čas«; Bevk 1923: 96).
} 
je naplavila duševne bolnike, morilce, rablje, samomorilce, blazneže, razdrla družine, uničila zaupanje med možem in ženo, prebudila najnižje strasti v človeku. Na fronti in po domovih je vse polno poblaznelih ljudi, vojaki živijo v predsmrtni grozi, doživljajo čustvene izbruhe (Klic žene), celo močne halucinacije (Zlo, Tri suhe hruške), blaznijo tudi dekleta in žene (Pismo). Duševno stisko doživlja celo ostarel človek. Starca brez las in zob je vojna pregnala v begunsko zatočišče, tam govori zmedeno in očitajoče, njegov govor je »nejasen in lajajoč« (Begunec). Vojna je povzročila popolno razčlovečenje človeka, kar ponazarja tudi animalizacijska metaforika, temelječa na konceptualni metafori ČLOVEK JE ŽIVAL. Med živalskimi izhodišči se pojavljajo živali (pes, volk, jastreb, miš, hijena), ki preslikujejo na človeka in v pokrajino pomenke, kot so zverinsko, divje, nagonsko, nasilno, pobesnelo, pritlehno in grdo. Izrazit primer razčlovečenja je v grotesknem prizoru črtice Tri suhe hruške. Skupina pobesnelih vojakov plane na enega od tovarišev, ker ima ta kos kruha, ki ga ne želi z nikomer deliti. Vojaki so naenkrat podobni volkovom:

Postali so grozni in grdi, stiskali so pesti, kleli in se režali s strčečimi belimi zobmi ...

Nekdo je stegnil roko kot blisk in mu izvil krajec iz rok ter krohotaje pobegnil. Planili so za njim drugi kot volcje (Bevk 1923: 23).

$\mathrm{V}$ nadaljevanju so vojaki poimenovani z zverjo in primerjani z jastrebom (»Zver se je pomirila in se zasmilila vase kot ponosen jastreb v kletki« (Bevk 1923: 24)).

V vlogi animalizacije so tudi epiteti (»lajajoč govor«, »volčji blesk«, »strčeči zobje «), žarišča glagolskih metafor (»ga je grizlo v duši«, »se pase popačeno gorje«, »Svetloba dneva se mu je čudno plazila po gubah obraza «) in primere (»Bal se je (kralj), da ljudje padejo ta hip nanj kot hijene« (Bajka), »me gleda z rdečimi in izbuljenimi očmi kot strta miš« $(Z l o))$.

\subsubsection{Metaforika in žanrska hibridnost}

Že Miran Jarc (1924: 699) je v kritiki Rabljev opozoril, da metaforični postopki v Bevkovih črticah - te je imenoval »kriki prebujene vesti« - razen v posameznih primerih nimajo pomembnejše vloge. Še najizrazitejša je metaforizacija zvočnih pojavov, ponekod se opazneje zapisujejo tudi čustveni in barvni pridevki. Zaradi politične cenzure je začel Bevk kmalu po prvih objavljenih črticah protivojne ideje nekoliko zakrivati in izražati v modificiranih paraboličnih in pravljičnih žanrih ter z ustreznimi stilnimi postopki, ${ }^{11} \mathrm{kar}$ se dovolj očitno pokaže že v besedilih, kot so Črni piščanec (DS 1915), Faraon (DS 1917), Bajka, Kralj Asram (DS 1919), v katere so vključene zgodbe z živalskimi, svetopisem-

${ }^{11}$ Bolj posredno izražanje je Bevku svetoval tudi Ivan Cankar (»Prehud izraz imaš, prejasen. Zavij ga, zakrij ga, saj so tepci in ne razumejo kmalu. Ideja naj bo močna in ne izraz, ta naj udari. Ideja naj udari, ne izraz«, Mladika 1922, 29, cit. po Koblar 1951: 16). 
skimi, pravljičnimi, bajeslovnimi in orientalskimi motivi, ki slednjič prerastejo $\mathrm{v}$ parabole za človekovo bivanjsko stisko in zmaličenost medčloveških odnosov.

$\mathrm{V}$ žanrsko hibridnih črticah ${ }^{12}$ je Bevk najpogosteje posegal po folklornih pripovednih žanrih. Ti so s seboj prinesli ne le posebno motiviko, ampak tudi svoje jezikovnostilne značilnosti, kot so antitetično uporabljeni stalni okrasni pridevki (mlada kraljična, star kralj, trpeče ljudstvo, trdosrčen kralj), hiperbolizacija, klišejska metafora, personifikacija kot strukturni element ljudskega žanra itd. Ker navedeni diskurzi ne prenesejo izvirne metafore ali pa se metafora kot stilna figura $\mathrm{v}$ njih celo ukinja, ${ }^{13}$ je to dejstvo potrebno upoštevati tudi pri določitvi avtorjevega stila. Poglejmo si to na primeru žanrsko hibridne pripovedi Faraon, po kateri je naslovljena tudi prva zbirka Bevkovih črtic. S tematizacijo krika po novem človeku in s himničnim nagovorom na ženo, ki bo nekoč $\mathrm{v}$ prihodnosti rodila novega človeka, je primer Bevkovega mesijanskega ekspresionizma. Toda med uvodni in sklepni himnični nagovor ženi je vložena tudi pretrgana zgodba o krutem faraonu in trpečem ljudstvu. Pripoveduje jo ljudski pripovedovalec, metabesedilno se do nje ves čas opredeljuje in jo napove kot pravljico o bridki resničnosti, o grozi, ki je ni mogoče opisati. Pri tem posega po nekaterih značilnostih pravljičnega žanra (literarni liki, moralna polarizacija oseb, trojnost motiva - možje, matere in otroci stopijo pred okamnelega faraona in ga zaman prosijo milosti). Zgodba ljudskega pripovedovalca se obenem medbesedilno navezuje na predlogo o suženjskem trpljenju izraelskega ljudstva v Egiptu. Tudi v Faraonu faraonovi služabniki tlačeno ljudstvo neusmiljeno pretepajo, vklenejo v verige, ob Nilu gradi to ljudstvo faraonu višjo piramido, kot jo je imel Keops, faraon da pomoriti vse prvorojence $v$ deželi, starec, ki mu v veliki žalosti prisluhne trpeče ljudstvo, spominja na Mojzesa itd. Navezave na pravljično in svetopisemsko predlogo poudarjajo odmik od enkratne in konkretne pripovedi $\mathrm{k}$ splošni veljavnosti, paraboli o trpljenju ljudstva in tiraniji oblastnikov. Obenem pa skupaj z ljudskim pripovedovalcem narekujejo tudi jezikovni izraz, težnjo po neposrednem govoru, ljudskem hiperboliziranju, tipiziranem in kontrastnem označevanju oseb. Epiteti za trdoto in kamen s ponavljanjem poudarjajo faraonovo trdosrčnost in prehajajo $\mathrm{v}$ funkcijo stalnega okrasnega pridevka (kamenit obraz, kamenit pogled, mrtvo oko, mrtev pogled).

Črni piščanec je primer žanrsko hibridne črtice s preprosto parabolično zgodbo iz živalskega sveta. Mladenič, ki je prestal zaporno kazen, se v poštnem vozu zaplete $\mathrm{v}$ pogovor $\mathrm{z}$ napol neznanim človekom, avtorskim pripovedovalcem, in mu pove tudi zgodbo o koklji, ki med rumenimi piščanci ni marala

12 Žanrsko hibridno črtico razumemo kot primer literarnega diskurza, za katerega je značilno, da sprejema vase tudi druge žanre in diskurze, tako da se ti žanru, v katerega vstopajo, bolj ali manj prilagodijo, obenem pa ne izgubijo svojih osnovnih žanrskih značilnosti.

${ }^{13}$ Tipičen primer, kako folklorni pripovedni žanr ukinja metaforo kot stilno figuro, je denimo personifikacija $\mathrm{v}$ pravljici, saj je antropomorfizacija narave, živali in rastlin strukturni element pravljičnega žanra kot takega, zato je personifikacija v njem razumljena kot temeljni način izražanja in ne kot stilna figura. 
črnega, čeprav se je ta izvalil iz njenega jajca. Preprosta vložna zgodba temelji na modifikaciji frazeološke živalske metafore (biti črna ovca v biti črn pišča$n e c$ ) in je seveda parabola za fantovo bivanjsko stisko, za njegovo izločenost in zavrženost. Po prestani zaporni kazni se nima več kam vrniti, v mrzli zimski noči izstopi iz poštnega voza v noč, povsem izločen in zavržen.

\subsubsection{Pisemske črtice}

V okviru žanrsko odprtih črtic pa tudi z vidika metaforike predstavljajo posebno skupino štiri pisemske črtice (V kritju, Klic žene, Praznota in Pismo). Seveda gre za simulacijo tega neliterarnega žanra oziroma za tako imenovano fiktivno pismo, ki pa vendarle želi učinkovati kot dokument realnega življenja oziroma neliterarni žanr (Kralj 2006: 205), zaradi česar ohranja tudi svoje Žanrsko prepoznavne stilne značilnosti (npr. klišejski začetek in konec pisma). Zapisovalke Bevkovih pisem so osamljene, čustveno razbolele, na smrt obupane žene in dekleta, obenem pa se razkrivajo tudi kot izrazito čutna bitja, ki želijo s svojim fantom ali z možem izživeti tudi erotično strast. Toda med njimi so »jeklene gore«, on jih ne more prebiti in ona ne more do njega (Klic žene).

Žene in dekleta izpovedujejo navale strasti, tudi nezaupljivost, ljubosumje, občutke odtujenosti in še zlasti bojazen, da bodo postale nezveste ali ostale za zmerom same, osramočene in zaničevane. Čeprav se ženska opredeljuje kot izrazito čutno bitje in zase pravi, da se lahko uresniči le z moškim kot njegova »nerazdružna«, »neločljiva«, bi o kakšni izraziti čutno/duhovni polarizaciji spolov težko govorili, saj ju ločuje in medsebojno oddaljuje zunanja sila, vojna, obenem pa je $v$ teh črticah trpeče bitje tudi moški. Za zapisovalko pisem je vsaka beseda solza (Klic žene), moški naslovnik pa toži, da v vojski nihče ne vidi »rane na srcu« (Klic žene). Tako moški (Klic žene, V kritju) kot ženska (Pismo) razrešujeta svojo čustveno stisko celo s samomorom. Bolj kot nasprotje spolov v smislu čutno/razumske polarizacije moškega in ženskega elementa prihaja v teh črticah v ospredje podrejena vloga ženske v patriarhalni družbi. Ženske se bojijo za svojo moralno podobo v smislu zveste zakonske žene in matere. Brez moža ali fanta so šibke kot otrok ( $V$ kritju), nerodovitne, zapostavljene (Praznota), ogrožena je njihova zvestoba (Klic žene, $V$ kritju), bojazen pred očitki nezakonske nosečnosti jih vodi celo v samomor (Pismo). Noseče dekle hoče obdržati svojega nekdanjega fanta tudi z obljubo, da bo njegova dekla (Pismo). Vse to ponazarjajo tudi primere in identifikacije za žensko:

Na vrtu je nekdo vzel kol, ki je podpiral rožo. Sneg je padel nanjo in se je zlomila. Ali boš hud? (Bevk 195: 172);

Kako sem šibka, zaničevana, brez moči, ko sem sama! Poljana sem - ni dežja - suha ležim, rjava, izpremenjena v prah. Cvetica sem - sonca ni - brez vonja in barve ginem v noči, požgana od slane. Glas sem - gluh se je odbil v daljavo (Bevk 1951: 192);

Jaz še najšibkejši otrok ne morem več biti --- (Bevk 1951: 204). 
Osebnoizpovedna in največkrat intimna vsebina pisem je zapisana z izrazito čustveno besedo, veliko je retoričnega govora, nagovorov, vprašanj, vzklikov, stopnjevanja in ponavljanja, bolj kot drugje pa je prisotna tudi čustvena metaforika. Vizualizacijo in intenziteto duševnih ter miselnih pojavov ponazarjajo primere in metafore z najopaznejšimi izhodiščnimi območji krvi in ognja (besede, misli, čustva gorijo, krvavijo, pečejo):

/... / je ležala vznemirjenost zapisanih besed, gorečih kot srce, še v prstih blede roke so ji trepetale (Bevk 1951: 191);

Kolikokrat krvavijo vaše misli (Bevk 1951: 204);

Tako mi je, kot da bi mi kdo spuščal žareče oglje v dušo (Bevk 1951: 176);

Pisma so ga žgala na prsih (Bevk 1951: 176);

Strašno me peče, ta ogenj moramo pogasiti (Bevk 1923: 90).

\subsubsection{Barvna simbolika}

Bevkove vojne črtice so dogajalno postavljene v majhne prostore (vlak, poštni voz, lesena baraka, strelski jarek, soba idr.) in v mračno, deževno ali zasneženo pokrajino, v kateri je polno razglašenih glasov, krikov, prepadov, neprijetnega šumenja vode. $V$ takšnih prostorih se nahajajo na smrt prestrašeni vojaki, duševni bolniki, pogosti blazneži in samomorilci. Odtod so izginile tudi svetle barve kot tradicionalni simboli življenja, ${ }^{14}$ nad vsemi je zavladala črna s simbolnimi pomeni smrti in žalosti (črna kri, črna vest, črna zaveza, obupan kot črna noč). Ob tej se zapisuje tudi rdeča, in sicer kot barva krvi s simbolnimi pomeni bolečine in umiranja (rdeče rane, rdeče izbuljene oči, krvav nagelj, žareče oglje). Na bližino smrti in predsmrtno prestrašenost prav tako opozarjajo pogosti epiteti za bledost (bledikast fant, mlad vojak, lice mlečno, blede roke, obraz, bled kot namizni prt, obrazi pobledeli, bled obraz), blaznost (blazen vojak, blazna misel) pa tudi črno-blede (»bled obraz s črnimi brki«, Klic žene) in črno-rdeče kombinacije (»Črno bom oblečena, krvav nagelj bom nosila na prsih «, Pismo). Z vidika abstraktnih barvnih metafor je posebej zanimiva črtica Tri suhe hruške ${ }^{15}$ (Mentor 1917/1918), nekakšen nekrolog, kakor pravi prvoosebni pripovedovalec, vsem tistim, ki v vojni niso umrli od krogle ali jetike, ampak od »mrzle vročine črnih in zelenih sonc«, torej od blaznosti.

${ }^{14}$ Barve so ohranila le še osamljena dekleta, svoja pisma pišejo na zelen ( $V$ kritju), rdečkast papir (Praznota) ali z vijoličastim črnilom (Klic žene). Nekaj barvne pisanosti prinašajo tudi žanrsko hibridne črtice z modificiranimi ljudskimi žanri.

${ }^{15}$ Črtica Tri suhe hruške je ena redkih, ki izpoveduje upanje, da je človek kljub vojni moriji v svoji notranjosti še ohranil kanček človečnosti. V tem smislu spominja na Cankarjevo Mojo kamrico. Blaznež v Bevkovi črtici po navalu pobesnele množice vendarle ponudi košček kruha vojnemu tovarišu, ker si je »zaklenil v srce«, da je ta nekoč delil z njim suhe hruške. 
Med blaznimi vojaki so postale halucinacije že nekaj povsem vsakdanjega, kar ponazarja že zgoraj omenjena abstraktna barvna metafora črnih in zelenih sonc.

\section{Sklep}

Novejše raziskave potrjujejo, da je začetek slovenske ekspresionistične kratke proze sovpadel z začetkom prve svetovne vojne, ko je začela objavljati ob Ivanu Cankarju tudi skupina mladih avtorjev (France Bevk, Stanko Majcen, Ivan Dornik, Narte Velikonja idr.) v reviji Dom in svet distorzične psihološke črtice s protivojno tematiko. Na model sanj, ki je po Soklovem prepričanju odločilnega pomena za izražanje ekspresionističnih duhovnih in podzavestnih duševnih stanj, zlasti kar zadeva nejasne prehode med realnim in irealnim svetom, nepovezane, a vizualno učinkovite simbolne podobe, kaže že naslov Cankarjevih Podob iz sanj, najdemo pa ga tudi v primerih Dornikove kratke proze (Konji). Pri Bevku prihajata najmočneje do izraza groteskna podoba in parabolizacija. Fragmentarne zgodbe njegovih vojnih črtic imajo pogoste metabesedilne prekinitve in so nekakšne monološke ter dialoške psihološke skice, polne obupnih klicev in v dogodke zgoščenih bolečin. Po notranjem stilu so največkrat dramatične in patetične, kot njihova opazna značilnost pa se pokaže tudi žanrska hibridnost. Pisatelj je rad posegal po izpovedni, zlasti pisemski obliki, zapisoval monološke pripovedne scene, dramatske dialoge ter modifikacije folklornih žanrov. V jezikovnem stilu imajo mestoma osrednjo vlogo ogovorne figure, zapisani so himnični nagovori, retorični vzkliki, kriki, ki ponazarjajo napeta duševna stanja, medtem ko je metafora razen v nekaterih primerih manj izrazita.

Novembra lani so potekala slavja ob devetdesetletnici konca prve svetovne vojne. To je bila vojna, ki je zahtevala deset milijonov smrtnih žrtev in dvakrat toliko ranjencev, vojna, ki je usodno potekala tudi na naših tleh in na novo zarisala podobo Evrope, vojna, o kateri so tedaj mislili, da je ne bo nikoli več. Slovenska zgodnja ekspresionistična kratka proza je nastala kot idejni in stilni protest zoper to vojno morijo. $\mathrm{Z}$ nadnacionalnimi, etično poglobljenimi temami in novo slogovno izraznostjo je pomemben del evropske ekspresionistične literature. V današnjem času, ko so etične vrednote na vseh področjih človekovega delovanja prezrte bolj kot kdaj koli poprej, je ekspresionistični klic po novem človeku oziroma po etičnem humanizmu, kar je bila pomembna tema te proze, več kot aktualen.

\section{LITERATURA}

France BEVK, 1922: Faraon. Trst: Naša založba.

--, 1923: Rablji. Gorica: Narodna knjigarna. 
- -, 1951: Izbrani spisi. Prva knjiga. Ur. France Bevk in France Koblar. Ljubljana: DZS.

Ivan CANKAR, 1975: Zbrano delo, 23. Ljubljana: DZS.

Izidor CANKAR, 1968: Leposlovje - eseji - kritika. Prva knjiga. Ljubljana: Slovenska matica.

Jožica ČEH, 2001: Metaforika v Cankarjevi kratki pripovedni prozi. Maribor: Slavistično društvo. (Zora, 13).

--, 2006: Majcnova kratka proza v kontekstu moderne in njene slogovne značilnosti. Slavistična revija 54/3, 379-389.

- -, 2006a: Metaforika v Cankarjevih Podobah iz sanj. Slovenska kratka pripovedna proza. Ur. Irena Novak Popov. Ljubljana: Filozofska fakulteta. (Obdobja, 23). 569-580.

Marjan DOLGAN, 1996: Tri ekspresionistične podobe sveta. Ljubljana: ZRC SAZU.

Walter FÄHNDERS (ur.), 2001: Expressionistische Prosa. Bielefeld: Aisthesis Verlag.

Helga GLUŠIČ: Slovenska ekspresionistična kratka proza. Obdobje ekspresionizma $v$ slovenskem jeziku, književnosti in kulturi. Ur. Franc Zadravec. Ljubljana: FF. (Obdobja, 5). 117-122.

Miran JARC, 1924: France Bevk: Rablji. Ljubljanski zvon 34, 688-699.

Inge JENS, 1997: Die expressionistische Novelle. Tübingen: Atempto V.

Alenka JENSTERLE DOLEŽAL, 2006: Splet norosti in erotičnih obsesij v Grumovi prozi (subjektivizem Grumove proze). Slovenska kratka pripovedna proza. Ur. Irena Novak Popov. Ljubljana: Filozofska fakulteta. (Obdobja, 23). 97-110.

Hans-Georg KEMPER in Silvio VIETTA, 1990: Expressionismus. München: Wilhelm Fink Verlag.

France KOBLAR, 1924: France Bevk: Rablji. Ljubljanski zvon 34/6, 256-257.

--, 1951: Delo Franceta Bevka. France Bevk: Izbrani spisi. Prva knjiga. Ur. France Bevk in France Koblar. Ljubljana: DZS. 5-64.

Gregor KOCIJAN, 2006: Slovensko kratko pripovedništvo 1922-1924 (starejših generacij). Slavistična revija 54/3, 329-348.

Juš KOZAK, 1923: France Bevk: Faraon. Ljubljanski zvon 33, 378.

Lado KRALJ, 1986: Ekspresionizem. Ljubljana: DZS. (Literarni leksikon, 30).

- -, 2006: Dnevnik in pismo kot modela kratke proze med vojnama. Slavistična revija 54/2, 205-220.

Wilhelm KRULL, 1984: Prosa des Expressionismus. Stuttgart: Metzler.

Stanko MAJCEN, 2000: Zbrano delo, 8. Ur. Goran Schmidt. Ljubljana: DZS.

Katja MIHURKO PONIŽ: Kratka pripovedna proza Marije Kmet. Slovenska kratka pripovedna proza. Ur. Irena Novak Popov. Ljubljana: Filozofska fakulteta. (Obdobja, 23). $73-86$. 
Krešimir NEMEC, 2002. Hrvatska ekspresionistička proza. Ekspresionizam u hrvatskoj književnosti i umjetnosti. Ur. Branimir Bošnjak, Cvetko Milanja idr. Zagreb. 85-96.

Bernd SCHEFFER, 1982: Expressionistische Prosa. Deutsche Literatur. Eine Sozialgeschichte. Ur. Horst Albert Glaser. Reinbek: Rowohlt. 297-312.

Walter H. SOKEL, 1970: Der literarische Expressionismus. München.

Bojana STOJANOVIĆ PANTOVIĆ, 2003: Morfologija ekspresionističke proze. Beograd: Artist.

- -, 2006: Strukturne razsežnosti slovenske kratke ekspresionistične proze. Slavistična revija 54/1, 33-40.

August STRINDBERG, 1917: Märchenspiele. Ein Traumspiel. Prev. Emil Schering. München, Leipzig.

Franc ZADRAVEC, 1993: Slovenska ekspresionistična literatura. Murska Sobota, Ljubljana: Pomurska založba, Znanstveni inštitut FF.

\section{EARLY SLOVENE EXPRESSIONIST SHORT NARRATIVE PROSE AND ITS STYLISTIC FEATURES}

Earlier studies of expressionist literature somewhat stereotypically see expressionist prose as weak and insignificant. However, since the 1980s, the German as well as the south Slavic cultural space has witnessed an intense interest in expressionist prose. As the basic principle of expressionist poetics, intensity defined the image of this literature in terms of ideas and themes as well as structure and style, ousting from it particularly its epic character. From this point of view, the frequently mentioned thesis that the expressionist stylistic paradigm could not assert itself (successfully) in narrative prose is quite understandable, but this can only hold for novels and not for short narrative prose, which since the end of the $19^{\text {th }}$ century has found strong support in non-epic styles and models. From this point of view, one can agree with the thesis of Bernd Scheffer (1982), who claims that expressionist features havedeveloped more in short narrative prose than in lyrical verse because of the open and variable models in prose.

Slovene literary history, too, paid less attention to expressionist prose, i.e. short narrative prose, than to drama and lyrical writing. It was Bojana Stojanović Pantović and her monograph Morfologija ekspresionističke proze (Beograd, 2003) who managed to draw greater attention towards it. Research has shown that the beginnings of Slovene expressionist narrative prose were shaped by the group of authors who during World War I published in Dom in svet (Ivan Cankar, France Bevk, Stanko Majcen, Ivan Dornik and Narte Velikonja). According to Walter Sokel, expressionist literature expressed the subject's spiritual and frequently subconscious mental states by making use of the structure of dreams, of blurred transitions between the real and unreal and of disconnected, but visually effective symbolic images. This stylistic device can be observed particularly in Cankar's Podobe iz sanj (Images from Dreams) as well as in Dornik's short prose, while early Bevk is a case of parabolic stylistic procedures and modifications of the fairy-tale genre. 